\title{
PEMANFAATAN MIKROKONTROLER AT89S51 SEBAGAI PENGGESER FASA PADA ANTENA ARRAY
}

\author{
Oleh : \\ Rikki Vitria \\ Jurusan Teknik Elektro Politeknik Negeri Padang \\ rikki_la_pdg@yahoo.com
}

\begin{abstract}
Utilization of microcontroller especially MCS-51 family has been widely implemented in various applications, such as control and telecommunications applications. One of them is the phase shifting array antenna in the telecommunication field. The Array Antenna was designed from some of dipole antenna. Each element at dipole antenna has a different phase and can be controlled electronically. The phase shifting was done using AT89S51 microcontroller that functioned as an electronic switch on the transmission cable connection. The phase of the array antenna will be moved without moving the structure of the array antenna itself, so that the direction of radiation pattern can be changed in accordance with the phase shifting between the antenna elements.
\end{abstract}

Keywords : Microcontroller AT89S51, Antenna, phase shifting, radiation pattern

\section{PENDAHULUAN}

Pemanfaatan mikrokontroler khususnya keluarga MCS-51 telah banyak diaplikasikan pada berbagai aplikasi. Mikrokontroler merupakan sebuah kemajuan teknologi semikonduktor yang dibentuk dari kandungan transistor yang lebih banyak, tetapi ditampung pada ruang yang kecil dan diproduksi secara masal. Sehingga mikrokontroler dapat mudah diperoleh dengan harga yang terjangkau. Disamping itu pembuatan sistem minimum yang menggunakan mikrokontroler ini tidak memerlukan tempat yang besar, sehingga sangat efisien digunakan untuk berbagai aplikasi pengontrolan dan telekomunikasi. Salah satu pemanfaatan mikrokontroler ini adalah pada pengontrolan parameter antena
Antena merupakan komponen yang sangat penting dalam telekomunikasi khususnya telekomunikasi radio, baik yang bersifat broadcast maupun point to point. Antena berfungsi sebagai transduser, yang mengubah gelombang listrik menjadi gelombang elektromagnetik pada ruang bebas. Setiap antena memiliki frekuensi kerja tertentu, dimana antena dapat memancarkan dan menerima gelombang secara optimal. Antena meradiasikan gelombang listrik menjadi gelombang elektro-magnetik pada ruang bebas akan membentuk pola tertentu yang disebut pola radiasi.

Radar merupakan salah satu jenis antena. yang pengarahan sinyal gelombang elektromagnetiknya melalui perputaran antena yang dikendalikan oleh motor penggerak. Motor penggerak ini memerlukan daya yang besar dalam apliksinya dan banyak membutuhkan 
biaya untuk perawatannya. Sementara itu antena array merupakan sebuah antena yang pancaran atau penerimaanya lebih besar pada suatu arah tertentu dan lebih kecil pada arah yang lain. Antena array dirancang sedemikian rupa dari beberapa antena dipole, dimana setiap elemennya memiliki fasa yang berbeda. Fasenya dapat digeser tanpa menggerakkan antena itu sendiri. Pergeseran fasa ini akan menyebabkan arah pola radiasi antenanya dapat diubah-ubah. Tujuan dari penelitian ini adalah membuat sebuah alat yang dapat merubah pola radiasi antena array tanpa harus merubah posisi antenanya.

\section{TINJAUAN PUSTAKA}

\section{Antena}

Sistem Telekomunikasi radio terdiri dari perangkat tramsmitter dan receiver. Transmitter berfungsi membangkitkan sinyal RF. Setelah sinyal RF dibangkitkat selanjutnya diradiasikan melalui ruang bebas menuju receiver. Perangkat yang melakukan proses radiasi ini disebut Antena. Energi sinyal dari Transmitter dikirimkan melalui media udara dengan menggunakan Antena pengirim, dan energi sinyal akan di tangkap pada receiver menggunakan antena penerima.

Energi RF dikirimkan melalui media udara dalam bentuk medan elektromagnetik. Medan Elektromagnetik tersebut menuju antena penerima, dan selanjutnya menginduksikan tegangan pada antena (berupa konduktor) di penerima. Induksi tersebut diteruskan ke receiver dan dikembalikan kedalam bentuk informasi.

\section{Pola Radiasi}

Radiasi dari suatu antena akan membentuk pola tertentu yang disebut pola radiasi. Pola radiasi dapat didefenisikan sebagai gambaran kekuatan pancaran/penerimaan sinyal suatu antena dalam fungsi sudut.

Bentuk umum pola radiasi antena dapat dilihat pada Gambar 1 (a) diperlihatkan bentuk pola radiasi antena pada sistem koordinat tiga dimensi. Sedangkan pada gambar 1 (b) diperlihatkan bentuk pola radiasi dalam koordinat polar (sudut).

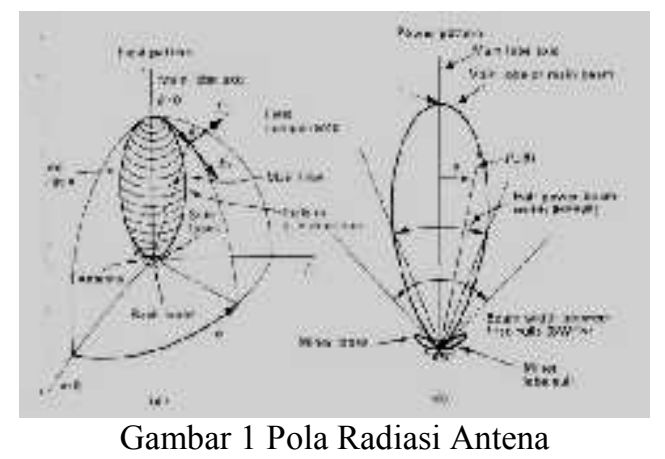

Polaradiasi dapat dibedakan beberapa macam yaitu:

1. Pola radiasi Omnidirectional

Pola radiasi omnidirectional adalah pola radiasi yang sama ke segala arah. Pola radiasi omnidirectional dihasilkan oleh antena isotropis. Dengan bentuk polaradiasi seperti ini memungkinkan pengguna menangkap sinyal disetiap penjuru antena pemancar sebagaimana Antena yang digunakan pada siaran radio atau pada telepon genggam. Kekurangan dari bentuk pola radiasi omnidirectional mempunyai jarak pancaran yang pendek sehingga daerah cakupannya kecil. Pola radiasi Omnidirectional dapat dilihat pada gambar 2 (a).

\section{Polaradiasi Bidirectional (dua arah)}

Polaradiasi Bidirectional adalah pola radiasi dua arah. Yaitu arah depan dan arah belakang antena.

\section{Pola radiasi Unidirectional}

Pola radiasi antena yang pancaran dan penerimaannya hanya satu tempat atau satu arah sebagaimana pada gambar 2 (c). Dengan bentuk pola radiasi seperti 
ini, pancaran antena mampu mempunyai jarak yang lebih jauh dibandingkan dengan antena berpolaradiasi omnidirectional apabila diasumsikan daya pancar kedua antena sama. Tetapi pola radiasi ini hanya bisa melingkupi suatu daerah pada arah tertentu.

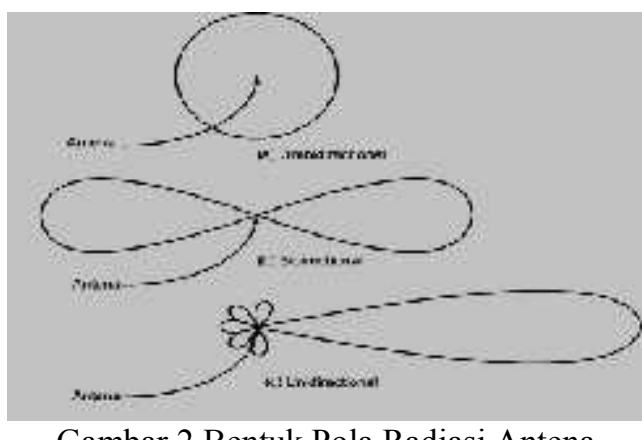

Gambar 2 Bentuk Pola Radiasi Antena

Pengukuran pola radiasi antena dapat dilakukan dengan mengukur level terima dari suatu antena dengan sudut antena pemancar bervariasi dari 0 sampai dengan $359^{\circ}$ dan menggambarkan setiap level pada fungsi sudut.

\section{Gain Antena}

Gain antena adalah perbandingan daya pancar suatu antena terhadap daya pancar antena referensi, atau pertambahan daya yang diradiasikan pada arah tertentu dari suatu antena dibandingkan dengan daya yang diradiasikan pada arah yang sama oleh suatu antena referensi. Gain antena disebut juga dengan power gain.

\section{Bandwidth Antena.}

Pemakaian sebuah antena dalam sistem pemacar atau penerima selalu dibatasi oleh daerah frekuensi kerjanya. Pada range frekuensi kerja tersebut antena dituntut harus dapat bekerja dengan efektif agar dapat menerima atau memancarkan gelombang pada band frekuensi tertentu. Pengertian harus dapat bekerja dengan efektif adalah bahwa distribusi arus dan impedansi dari antena pada range frekuensi tersebut benar-benar belum banyak mengalami perubahan yang berarti. Sehingga pola radiasi yang sudah direncanakan serta VSWR (Voltage Standing Wave Ratio) yang dihasilkannya masih belum keluar dari batas yang diijinkan. Daerah frekuensi kerja dimana antena masih dapat bekerja dengan baik dinamakan bandwidth antena. Suatu misal sebuah antena bekerja pada frekuensi tengah sebesar $\mathrm{f}_{\mathrm{C}}$, namun masih dapat bekerja dengan baik pada frekuensi $\mathrm{f}_{1}$ (di bawah $f_{C}$ ) sampai dengan $f_{2}\left(\right.$ di atas $\left.f_{C}\right)$, maka lebar bandwidth dari antena tersebut adalah $\left(f_{1}-f_{2}\right)$. Tetapi apabila dinyatakan dalam prosentase, maka bandwidth antena tersebut adalah :

$$
\mathrm{B}=\frac{f_{2}-f_{1}}{f_{c}} \times 100 \%
$$

Bandwidth yang dinyatakan dalam prosentase seperti ini biasanya digunakan untuk menyatakan bandwidth antena-antena yang memliki band sempit (narrow band). Sedangkan untuk band yang lebar (broad band) biasanya digunakan definsi rasio antara batas frekuensi atas dengan frekuensi bawah.

$$
\mathrm{BW}=\frac{f_{2}}{f_{1}}
$$

Suatu antena digolongkan sebagai antena broad band apabila impedansi dan pola radiasi dari antena itu tidak mengalami perubahan yang berarti untuk $\mathrm{f}_{2} / \mathrm{f}_{1}>1$. Batasan yang digunakan untuk mendapatkan $\mathrm{f}_{2}$ dan $\mathrm{f}_{1}$ adalah ditentukan oleh harga VSWR (Voltage Standing Wave Ratio) $=1$.

\section{Antena Array}

Antena array merupakan sistem yang terdiri dari sejumlah elemen radiasi yang umumnya sama yaitu di susun dan di bangkitkan untuk mendapatkan pola direksional. 


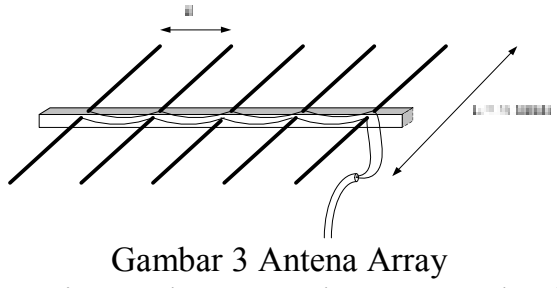

Setiap elemen akan memberikan peningkatan daya pancar/terima dari antena (power gain). Jadi semakin bertambah jumlah elemen maka power gain akan semakin tinggi.

Pada pembuatan elemen antena array yang terdiri dari antena dipole dapat dihitung dengan rumus berikut:

$$
\lambda=\frac{\mathrm{s}}{\mathrm{i}}
$$

dimana:

$\bar{\lambda}=$ Panjang gleombang $(\mathrm{cm})$

$\mathrm{c}=$ Kecepatan cahaya dalam

ruang hampa $\left(3 \times 10^{8} \mathrm{~m} / \mathrm{s}\right)$

$\mathrm{f}=$ frekuensi $(\mathrm{Mhz})$

untuk panjang antena digunakan rumus:

$$
L=\frac{1}{2} \text {. (2.8) }
$$

$$
\begin{aligned}
& \mathrm{L}=\text { panjang antena }(\mathrm{cm}) \\
& \bar{\lambda}=\text { Panjang gleombang }(\mathrm{cm})
\end{aligned}
$$

untuk menentukan Spasi (jarak elemen) tiap antena

$$
\mathrm{D}=1 / 2 \lambda
$$

dimana:

$$
\begin{aligned}
& \mathrm{D}=\text { spasi (jarak elemen) } \\
& \boldsymbol{\lambda}=\text { Panjang gleombang }(\mathrm{cm})
\end{aligned}
$$

Spasi (jarak elemen) pada elemen yang dicatu, bisa di tentukan sendiri asal tidak terlalu renggang atau dapat digunakan rumus:

$$
\mathrm{D}_{\mathrm{a}}=\mathrm{L}-\text { spasi yg di inginkan }(\mathrm{mm})
$$

Sehingga jarak panjang satu elemen antena adalah
$\mathrm{L}=\frac{D_{\text {ax }}}{2}$

(7)

Dimana:

$\mathrm{D}_{\mathrm{a}}=$ panjang elemen setelah

dikurangi spasi $(\mathrm{cm})$

$\mathrm{L}=$ panjang elemen

Pola radiasi antena array lebih besar pada arah tertentu dan lebih kecil pada arah yang lain. Pola radiasi yang dihasilkan antena array dinamakan Array Factor (AF) dengan persamaan dibawah ini

$$
A F=A_{0} \frac{\sin \left(N \frac{\psi}{2}\right)}{N \sin \left(\frac{\psi}{2}\right)}
$$

dimana:

$$
\begin{aligned}
& \mathrm{N}=\text { Jumlah Elemen } \\
& \mathrm{D}=\text { Jarak antar elemen } \\
& \mathrm{A}=\text { Puasat jari-jari AF } \\
& \psi=\beta d \cos \theta+\alpha \\
& \beta=\frac{2 \pi}{\lambda}
\end{aligned}
$$

\section{Saluran Transmisi}

Saluran transmisi yang digunakan yaitu kabel coaxial. Kabel Coaxial adalah kabel yang paling umum digunakan untuk transmisi sinyal video. Nama coaxial mengacu pada sumbu umum dari dua konduktor.

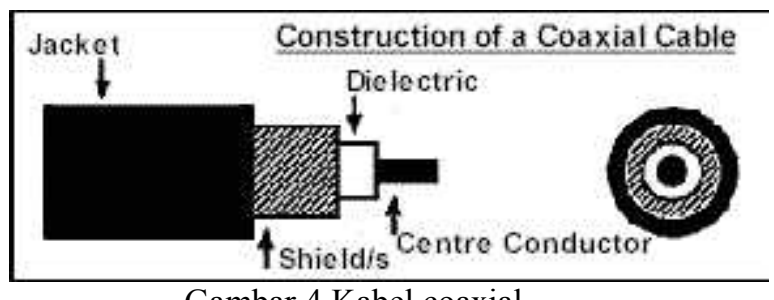

Gambar 4 Kabel coaxial

Sebuah kabel koaksial memiliki tembaga padat atau tembaga berlapis baja. Inti konduktornya dikelilingi oleh suatu bahan dielektrik isolasi nonkonduktif. Kebanyakan kabel koaksial digunakan untuk aplikasi video yang memiliki impedansi 75 ohm. Karakteristik yang berbeda listrik dan fisik membuatnya penting untuk memilih jenis kabel yang benar dan 
sesuai dengan aplikasi. Kabel koaksial yang sesuai dengan spesifikasi Pemerintah AS diidentifikasi dengan sebutan RG. Arti dari masing-masing kabel sebagai berikut:

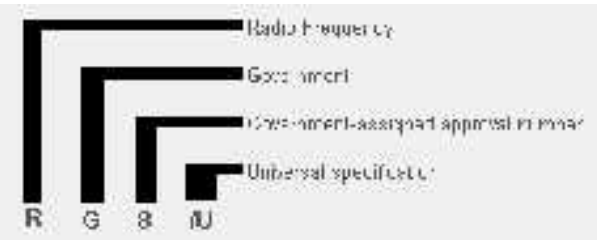

Gambar 5 Arti Masing-Masing Kabel

Jika huruf $\mathrm{A}, \mathrm{B}$ atau $\mathrm{C}$ muncul sebelum slash (/) itu menunjukkan spesifikasi modifikasi atau revisi. Sebagai contoh, RG 8 / U digantikan oleh RG 8A / U.

\section{Phase Shifter (Penggeser Fasa)}

Phase shifter (Robert R. Romanofsky,2007) adalah suatu perangkat untuk menggeser atau menambah fasa dari sinyal yang ditransmisikan pada system. Dalam aplikasi antena phase shifter digunakan untuk menggeser fasa sinyal yang di umpankan ke antena. Ada beberapa metoda yang bisa digunakan untuk menggeser fasa dari sinyal diantaranya Loaded line phase shifter, switched line phase shifter.

\section{a. High pass /Low pass phase shifter}

Penggunaan reaktansi variable secara seri atau shunt dapat digunakan untuk melakukan penggeseran fasa. Sebuah high pass/low pass phase shifter dengan model $\pi$ network menggunakan kapasitor diskrit ditunjukkan oleh gambar 8. Pada konfigurasi high pass yang ditunjukkan pada gambar, untuk kondisi circuit match, $X=2 \mathrm{~B} /\left(1+\mathrm{B}^{2}\right)$ dan fasa adalah sebesar $\tan ^{-1}\left(2 B /\left(B^{2}-1\right)\right)$. Sebagai saklar bisa digunakan PIN diode atau MESFETs. Dengan rangkaian ini memungkin melakukan penggeseran fasa sebesar $180^{\circ}$.



Gambar 6 High pass/low pass $\pi$ network phase shifter

\section{b. Loaded Line Phase Shifter}

Jenis phase shifter dengan loaded line ini memungkinkan penggeseran fasa $22.5^{\circ}$ sampai dengan $45^{\circ}$. Rangkaian dari loaded line phase shifter ditunjukkan pada Gambar 7. Beban reaktif pada gambar sepanjang $1 / 4$ panjang gelombang dipasang secara shunt pada saluran transmisi untuk menghasilkan penggeseran fasa. Susceptance kedua (jB) dipasang untuk menghasilkan pantulan, dimana secara terpisah menghilangkan pantulan pada susceptance pertama $(\mathrm{jB})$.

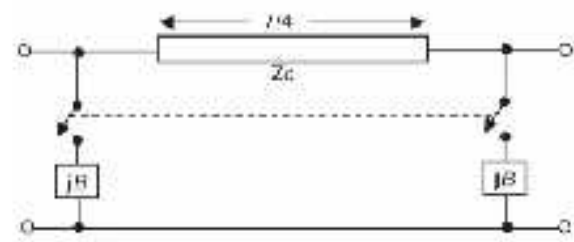

Gambar 7 Loaded line phase shifter

c. Switched line phase Shifter.

Switched line phase shifter ditunjukkan pada Gambar 8. Saklar SPDT digunakan untuk mengalihkan antara saluran transmisi yang mempunyai panjang yang berbeda. Berbeda dengan dua model sebelumnya, delay yang dihasilkan sesuai dengan dengan waktu (true time delay) sehingga memungkinkan menghasilkan fasa respon fasa yang sesuai dengan frekuensi. Pergeseran fasa diberikan oleh : 


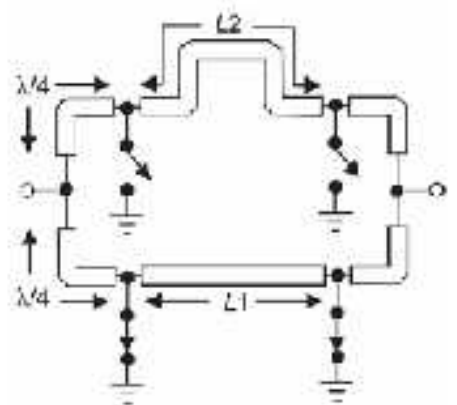

Gambar 8 Switched line phase shifter.

Dari ketiga model phase shifter yang dijelaskan diatas, switched line phase shifter yang memungkinkan penggeseran multi fasa sehingga memungkinkan digunakan untuk diaplikasikan untuk menggeser fasa variabel dari $0^{\circ}-360^{\circ}$.

\section{Mikrokontroller}

Mikrokontroller jika diterjemahkan secara harfiah, berarti pengendali yang berukuran mikro. Sekilas mikrokontroller hampir sama dengan mikroprosesor. Namun mikrokontroller mempunyai banyak komponen yang terintegrasi didalamnya, seperti timer/counter. Sedangkan pada mikroprosesor komponen tersebut tidak terintegrasi.

MCS-51 pertama kali dikembangkan oleh Intel Corporation pada tahun 70-an sehingga dapat dibilang usia MCS-51 telah lebih dari 24 tahun. MCS-51. Mikrokontroler ini merupakan salah satu keluarga mikrokontroller yang sampai sekarang masih banyak dikembangkan oleh berbagai produsen seperti Atmel Corp, Philips Semiconductors, Cygnal Integrated products,inc, dan Winbond Electronics Corp. Salah satu jenis dari mikrokontroller MCS-51 tersebut yang banyak digunakan pada saat ini yaitu jenis AT89S51.

Mikronkotroler AT89s5 memiliki konfigurasi pin-pin yang dapat dikelompokkan menjadi pin sumber tegangan, pin kristal, pin kontrol, pin input/output dan pin interupsi.

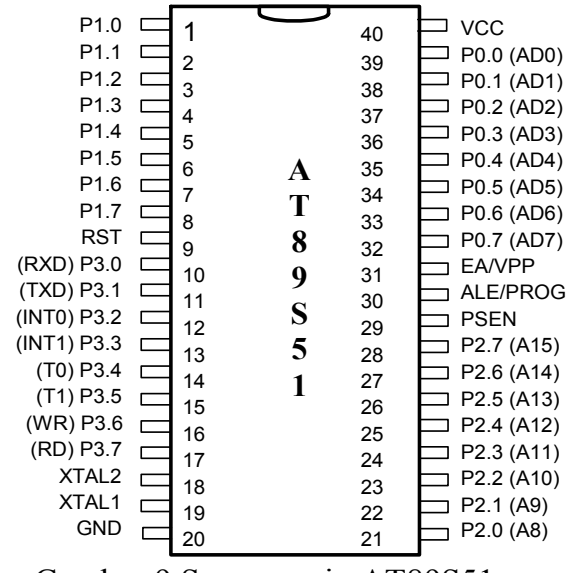

Gambar 9 Susunan pin AT89S51

Mikrokontroler AT89S51 buatan ATMEL ini memiliki fitur:

- PEROM (Programmable Erasable Read Only Memory) 4 kbyte untuk program

- RAM internal 128 byte

- In-System Programming

- 4 buah port I/O masing-masing 8 bit (P0 - P3)

- 2 buah Timer/counter 16 bit

- 5 buah sumber interupsi

- Sebuah port serial full duplex

- Tiga level penguncian program (menghindari pembajakan program)

- Memiliki mode operasi daya rendah

\section{Relay}

Relay adalah suatu peralatan listrik yang berfungsi melindungi, memutuskan atau menghubungkan suatu rangkaian listrik yang satu ke rangkaian yang lain, bekerja secara otomatis yang digerakkan oleh magnet. Relay berisi suatu kumparan yang apabila dimagnetisasi arus searah akan membangkitkan medan magnet yang akan memutuskan satu atau lebih kontak mekanis.

Kumparan relay yang mengoperasikan dua kontak terpisah yaitu S1 (terbuka normal) dan S2 (tertutup normal). Pada saat kumparan dilewati arus searah, S1 akan tertutup dan S2 akan terbuka. Setelah arus 
menghilang, kedua kontak kembali pada keadaan semula.

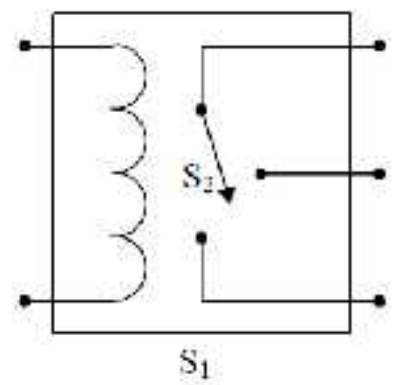

Gambar 10 Simbol Relay

\section{METODE PENELITIAN}

Perancangan dan pembuatan antena array dengan alat penggeser fasa secara swich elektronik dijelaskan pada blok diagram sebagai berikut:

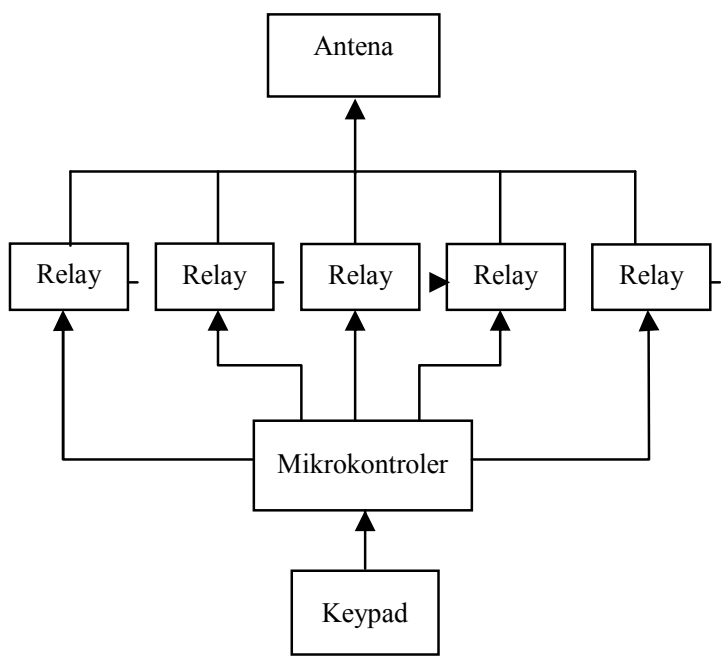

Gambar 11 Blok diagram alat penggeser phasa

Pada pembuatan penggeser fasa secara swich elektronik dapat dijelaskan bahwa swich elektronik menggunakan relay untuk mengaktifkan panjang kabel transmisi pada satu antena. Setiap antena memiliki lima (5) perubahan panjang kabel transmisi sehingga memerlukan lima (5) relay. Relay ini akan di kontrol oleh mikroprosesor AT89S51 dengan keypad yang memberikan input, Sehingga dapat menentukan panjang kabel transmisi yang digunakan untuk antena array, seperti yang terlihat pada Gambar 11.

\section{Pembuatan Antena Array}

Sebelum membuat antena terlebih dahulu merancang bentuk antena yang akan dibuat. Pada perancangan antena array ini dirancang antena 5 elemen dipole untuk menghasilkan arah maksimal yang berbeda-beda.

Adapun hal-hal yang perlu diperhatikan dalam merancang antena adalah :

a. Ukuran antena atau panjang elemen tergantung pada frekuensi yang digunakan dan panjang gelombangnya.

b. Frekuensi kerja yang digunakan, disini menggunakan frekuensi sebesar 850Mhz. Penggunaan frekuensi $850 \mathrm{Mhz}$ ini karena pada frekuensi ini tidak ada pengguna seperti radio dan stasiun TV sehingga memudahkan dalam pengukuran antena.

\section{Perhitungan Panjang Elemen Dan Spasi Antena}

Antena array terdiri dari beberapa antena individual yang disusun secara parallel. Dalam pembuatan antena array ini menggunakan 5 antena dipole $1 / 27$ yang disusun sejajar. Dengan frekuensi kerja dari antena adalah $850 \mathrm{Mhz}$ maka dapat dihitung panjang elemen antena dengan menggunakan rumus persamaan 3 dan 4 yaitu:

$$
\begin{aligned}
& h=\frac{\pi}{\mathrm{t}} \\
& \lambda=\frac{3 \times 10^{\Xi_{m / s}}}{850 \mathrm{MHz}} \\
& \lambda=0,35294 \mathrm{~m} \\
& \lambda=35,29 \mathrm{~cm}
\end{aligned}
$$

Jadi panjang elemen antena yang digunakan pada frekuensi $850 \mathrm{MHz}$ adalah 35,29 cm. sedangkan panjang elemen yang digunakan untuk 
perancangan yaitu $1 / 2 \bar{\lambda}$, maka didapat perhitungan sebagai berikut:

$$
\begin{aligned}
\mathrm{L} & =1 / 2 \lambda \\
& =1 / 2 \cdot 35,29 \mathrm{~cm} \\
& =17,64 \mathrm{~cm}
\end{aligned}
$$

Dari hasil diatas dapat diketahui bahwa panjang elemen antena dipole $1 / 2 \lambda$ adalah17,64 cm. Jarak elemen pada elemen yang dicatu, diberi spasi sebasar $2 \mathrm{~mm}$. sehingga dapat dihitung dengan persamaan 6 yaitu:

$$
\begin{aligned}
\mathrm{D}_{\mathrm{a}} & =\mathrm{L}-2 \mathrm{~mm} \\
& =17,64-0,2 \\
& =17,42 \mathrm{~cm}
\end{aligned}
$$

Jadi tiap satu elemen dikurangi dengan $1 \mathrm{~mm}$. Maka ukuran tiap satu elemen antena dapat dihitung dengan persamaan 7 yaitu:

$$
\begin{aligned}
\mathrm{L} & =\frac{D_{\mathrm{m}}}{\frac{2}{2}} \\
& =\frac{17,42 \mathrm{~cm}}{2} \\
& =8,71 \mathrm{~cm}
\end{aligned}
$$

Berdasarkan hasil perancangan diatas, maka antena dapat di rangkai dengan memasang tiap elemen antena pada kotak antena yang telah di beri konektor. Perangkaian antena ini dapat di lihat pada gambar berikut ini:

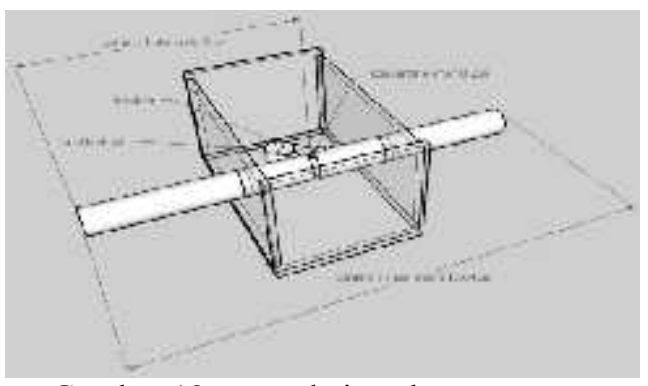

Gambar 12 perangkaian elemen antena

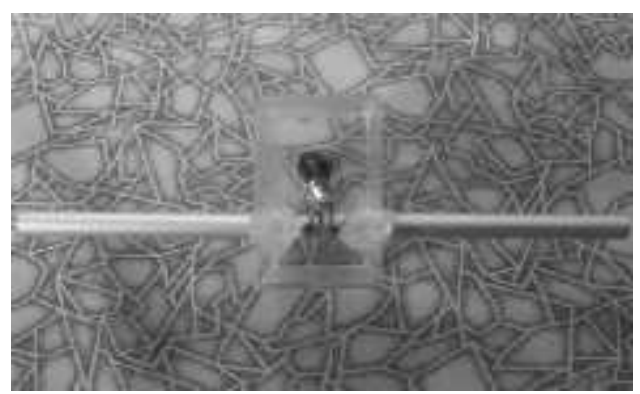

Gambar 13 Bentuk asli perangkaian elemen antena $\begin{array}{lrrr}\text { Selanjutnya } & \text { antena } & \text { tersebut } \\ \text { dipasang secara } & \text { sejajar } & \text { untuk } \\ \text { membentuk antena } & \text { array } 5 & \text { elemen. } \\ \text { Dalam menentukan } & \text { jarak satu antena } \\ \text { dengan antena lainnya } & \text { dapat }\end{array}$ menggunakan menggunakan persamaan dibawah ini:

$$
\begin{aligned}
\mathrm{D} & =1 / 2 \lambda \\
& =1 / 2(35,29 \mathrm{~cm}) \\
& =17,64 \mathrm{~cm}
\end{aligned}
$$

Jadi jarak antar antena adalah $17,64 \mathrm{~cm}$, sehingga antena dapat dirangkai secara sejajar seperti gambar berikut ini:

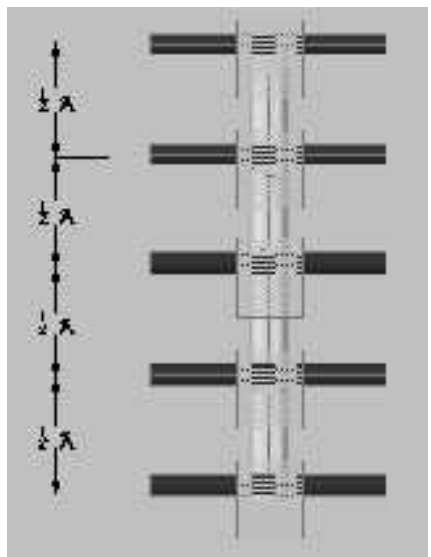

Gambar 14 pemasangan tiap antena pada tiang (tampak atas)

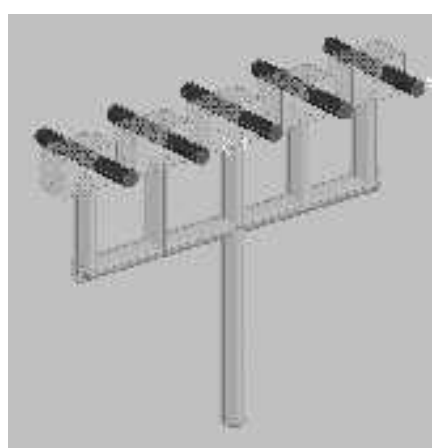

Gambar 15 pemasangan tiap antena pada tiang( tampak samping) 


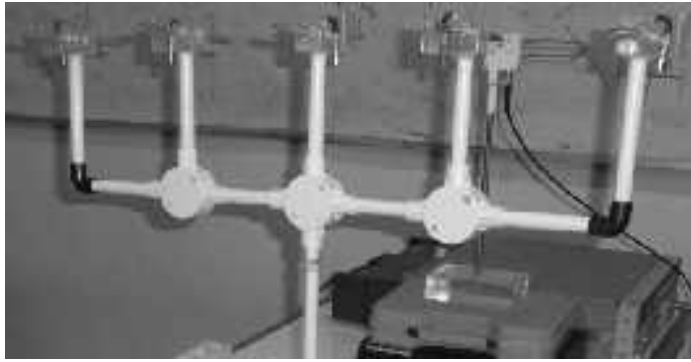

Gambar 16 Bentuk asli pemasangan antena pada tiang

\section{Kabel Transmisi}

Kemudian membuat kabel transmisi yang akan di pasang pada relay agar menghasilkan phasa pada sudut tertentu di antena array. Panjang kabel transmisi antena array dapat dilihat pada Tabel 1 dibawah ini.

Tabel 1 panjang kabel transmisi antena array

\begin{tabular}{c|c}
\hline Ukuran $(\lambda)$ & Ukuran $(\mathrm{Cm})$ \\
\hline $1 / 2 \lambda$ & $17,64 \mathrm{~cm}$ \\
$1 \lambda$ & $35,29 \mathrm{~cm}$ \\
$11 / 4 \lambda$ & $44,11 \mathrm{~cm}$ \\
$11 / 2 \lambda$ & $52,93 \mathrm{~cm}$ \\
$2 \lambda$ & $70,58 \mathrm{~cm}$ \\
\hline
\end{tabular}

Impedansi kabel yang digunakan adalah $75 \Omega$.

\section{Pembuatan Elektronik Swich Untuk Mengeser Phasa}

Pembuatan elektronik swich terdiri dari beberapa tahapan sebagi berikut:

\section{Rangkaian Pengendali (control)}

Rangkaian pengendali menggunakan sitem minimum yang berbasi mikrokontroler AT89S51. Adapaun gambar rangkaiannya seperti yang terlihat dibawah ini:

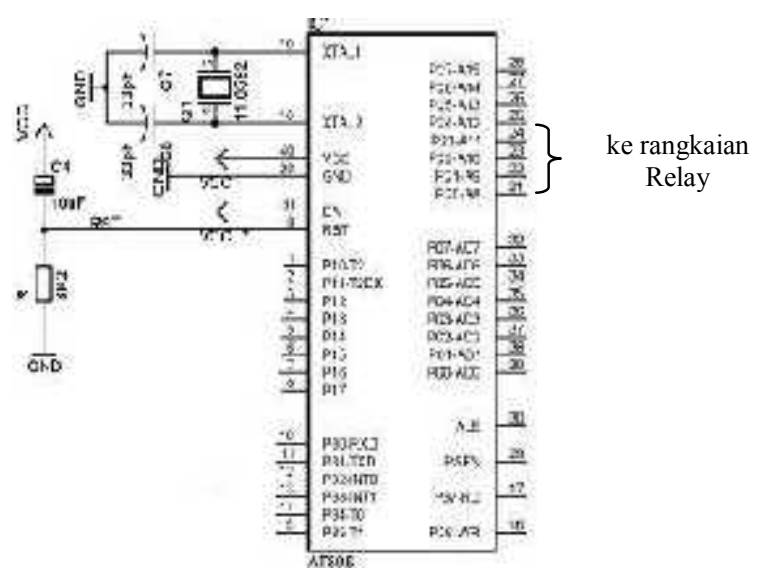

Gambar 17 Rangkaian Mikrokontroler AT89S51

\section{Rangkaian Keypad}

Rangkaian keypad berfungsi sebagai tombol untuk memasukan data ke mikrokontroler AT89s51 untuk diolah dan mengaktifkan relay. Rangkaian keypad di tunjukan pada gambar $\mathrm{d}$ bawah ini.

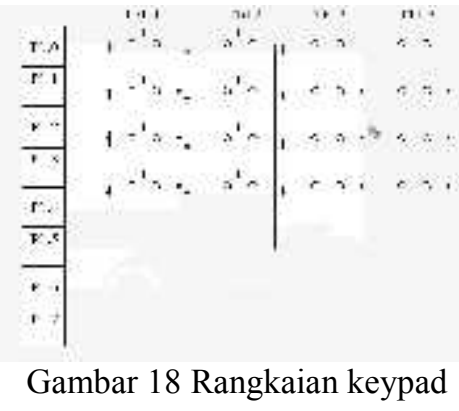

Rangkaian keypad yang di gunakan adalah rangkaian keypad 4 x 4 . Rangkaian keypad ini terdiri dari 16 tombol yang hubungan antara tomboltombolnya dapat dilihat padad gambar diatas. Keypad ini dihubungkan ke mikrokontroler AT89S51 pada Port1

\section{Rangkaian Relay dan Rangkaian LED Indikator}

Rangkaian relay pada alat ini berfungsi untuk memutuskan atau menghubungkan kabel transmisi untuk antena array dengan berbagai keadaan. Gambar rangkaian relay ini ditunjukkan pada gambar berikut ini: 


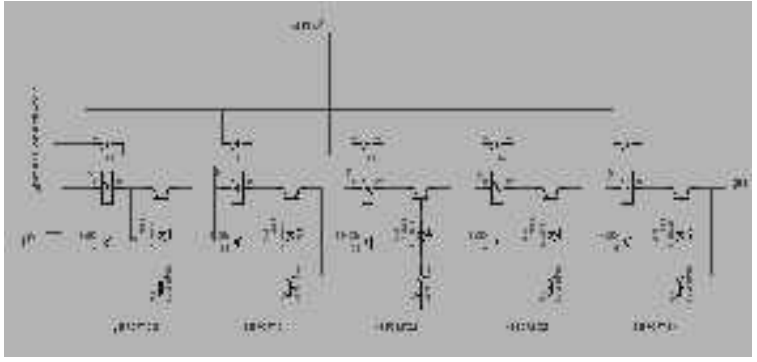

Gambar 19 Rangkain Relay dan Led indikator

Prinsip kerja rangkaian ini pada dasarnya memanfaatkan fungsi transistor sebagai saklar elektronik. Tegangan atau sinyal pemicu dari transistor berasal dari mikrokontroler Port 2.0 (P2.0) sampai Port 2.4 (P2.4). Pada saat logika salah satu Port 2.0 (P2.0) sampai Port 2.4 (P2.4) tinggi (high), maka transistor mendapat tegangan bias dari kaki basis. Dengan adanya tegangan bias ini transistor akan berada mengalami keadaan saturasi, sehingga adanya arus yang mengalir ke kumparan relay. Hal ini akan menyebabkan sakar pada relay menjadi tertutup, sehingga akan menghidupkan led indikator dan rangkaian kabel transmisi antena pada relay akan terhubung. Begitu juga sebaliknya pada saat logika salah satu Port 2.0 (P2.0) sampai Port 2.4 (P2.4) rendah (low) maka transistor tidak mendapatkan tegangan pada kaki biasnya. Pada keadaan ini transistor berada dalam kondisi cut off. Hal ini akan menyebabkan led indikator akan mati dan kondisi relay dalam keaadan normally open, sehingga hubungan antara kabel transmisi ke antena array tidak terhubung.

\section{HASIL DAN PEMBAHASAN}

\section{Pengukuran Beda Phasa}

Pengukuran beda phasa dilakukan agar alat penggeser phasa yang di buat untuk antena array dapat bekerja dengan baik. Hasil pengukuran terlihat pada Tabel 2 dibawah ini.

Tabel 2 Pergeseran phasa

\begin{tabular}{c|c|c}
\hline Panjang Kabel Transmisi & $\Delta \mathrm{x}(\mathrm{VPP})$ & $\begin{array}{c}\mathrm{X}_{\mathrm{T}} \\
(\mathrm{VPP})\end{array}$ \\
\hline $1 / 2 \lambda$ dengan $1 / 2 \lambda$ & 0 & 7.4 \\
$1 / 2 \lambda$ dengan $\lambda$ & 0.2 & 7.4 \\
$1 / 2 \lambda$ dengan $1 \frac{1}{4} \lambda$ & 0.3 & 7.4 \\
$1 / 2 \lambda$ dengan $1 \frac{1}{2} \lambda$ & 0.5 & 7.4 \\
$1 / 2 \lambda$ dengan $2 \lambda$ & 0.9 & 7.4 \\
\hline
\end{tabular}

\section{Pengukuran Bandwidth Antena}

Untuk pengukuran frekuensi bandwidth dari antena array bertujuan untuk mengetahui range frekuensi kerja dari antena yang dibuat. Hasil pengukuran terlihat pada Tabel 3 dibawah ini

\begin{tabular}{c|c|c}
\multicolumn{3}{c}{ Tabel 3 Hasil pengukuran bandwith antena } \\
\hline No & Frekuensi (Mhz) & $\begin{array}{c}\text { Daya terima } \\
\text { (dBm) }\end{array}$ \\
\hline 1. & & -61 \\
2. & 820 & -61 \\
3. & 821 & -60 \\
4. & 822 & -60 \\
5. & 823 & -60 \\
6. & 824 & -60 \\
7. & 825 & -59 \\
8. & 826 & -59 \\
9. & 827 & -59 \\
10. & 828 & -58 \\
11. & 829 & -58 \\
12. & 830 & -58 \\
13. & 831 & -57 \\
14. & 832 & -57 \\
15. & 834 & -56 \\
16. & 835 & -55 \\
17. & 836 & -55 \\
18. & 837 & -56 \\
19. & 838 & -56 \\
20. & 839 & -57 \\
21. & 840 & -58 \\
22. & 841 & -59 \\
23. & 842 & -59 \\
24. & 843 & -60 \\
25. & 844 & -60 \\
26. & 845 & -60 \\
27. & 846 & -60 \\
28. & 847 & -60 \\
29. & 848 & -61 \\
30. & 849 & -61 \\
\hline & 850 & \\
\hline
\end{tabular}

Berdasarkan hasil pengukuran pada frekuensi Tabel 2 diatas terlihat bahwa pada frekuensi $820-823 \mathrm{MHz}$ daya terima yang didapat adalah $-57 \mathrm{dBm}$, pada frekuensi $824-831 \mathrm{MHz}$ besar daya terimanya adalah $-56 \mathrm{dBm}$, pada frekuensi $832-841 \mathrm{MHz}$ daya terima yang diperoleh adalah $-55 \mathrm{dBm}$, dan pada frekuensi 842-850 daya terima yang didapatkan adalah $-56 \mathrm{dBm}$ 
Dari data diatas dapat diketahui bahwa range frekuensi maksimum berada pada frekuensi $832 \mathrm{MHz}$ sampai $841 \mathrm{MHz}$ dengan daya $-55 \mathrm{dBm}$. Range frekuensi ini merupakan frekuensi kerja dari antena atau disebut juga dengan bandwith. Bandwidth antena sangat dipengaruhi oleh luas penampang konduktor yang digunakan serta susunan fisiknya (bentuk geometrinya).

$$
\begin{aligned}
\text { Bandwith } & =\mathrm{f}_{2}-\mathrm{f}_{1} \\
& =841 \mathrm{MHz}-832
\end{aligned}
$$

$\mathrm{MHz}$

$$
=9 \mathrm{MHz}
$$

Frekuensi tengah antena $836,5 \mathrm{Mhz}$

\section{Pengukuran Pola Radiasi Antena}

Hasil pengukuran antena array di atas dengan $\lambda$ sama dapat digambarkan dalam bentuk polar berikut:

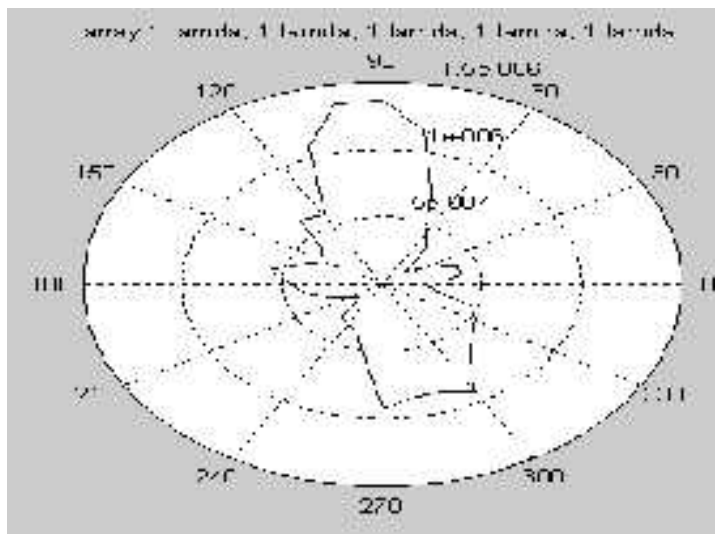

Gambar 20 hasil polaradiasi antena arrray horizontal dengan $\lambda$ sama

Dengan $\lambda$ yang sama pada antena array horizontal arah polaradiasi maksimum dari antena mengarah pada sudut $90^{\circ}$ dan $100^{\circ}$ dengan daya pancar $58,67 \mathrm{db}$ dan daya pancar minimum mengarah pada sudut $220^{\circ}$ dengan daya pancar $-68,67 \mathrm{db}$

Hasil pengukuran antena array horizontal di atas dengan variasi $1 / 2 \lambda, 1$ $\lambda, 11 / 4 \lambda, 11 / 2 \lambda$, dan $2 \lambda$ dapat digambarkan dalam bentuk polar berikut:

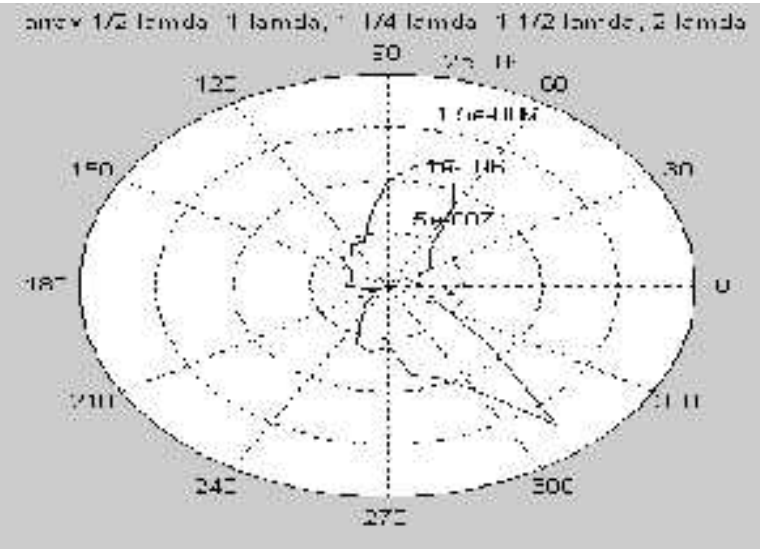

Gambar 21 Hasil polaradiasi antena arrray horizontal

dengan variasi $1 / 2 \lambda, 1 \lambda, 11 / 4 \lambda, 11 / 2 \lambda$, dan $2 \lambda$

Berdasarkan gambar diatas dapat di ketahui bahwa polaradiasi antena array dengan fariasi $1 / 2 \lambda, 1 \lambda, 11 / 4 \lambda, 11 / 2 \lambda$, dan $2 \lambda$ pada antena array arah pancaran maksimum mengarah pada sudut $310^{\circ}$ dengan daya pancar $-57,67 \mathrm{db}$ dan arah pancaran minimum mengarah pada sudut $210^{\circ}$ dengan daya pancar $-72,34 \mathrm{db}$

Hasil pengukuran antena arrray vertikal diatas dengan variasi $1 / 2 \lambda, 1 \lambda$, $11 / 4 \lambda, 11 / 2 \lambda$, dan $2 \lambda$ dapat digambarkan dalam bentuk polar berikut:

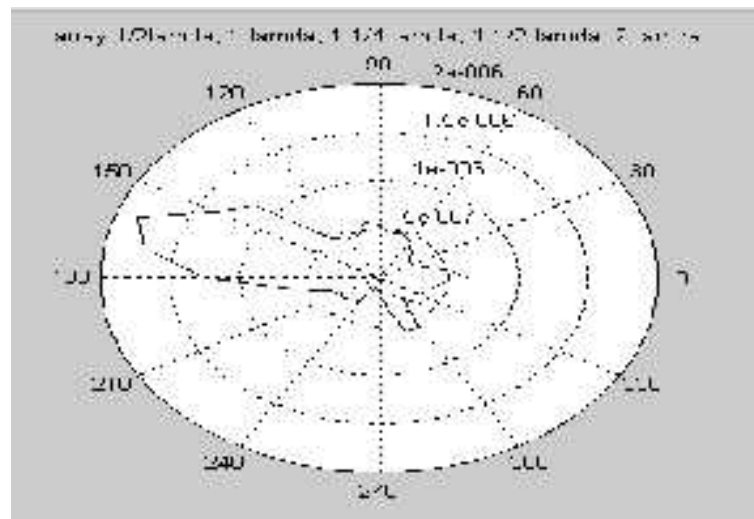

Gambar 22 Hasil polaradiasi antena arrray vertikal

dengan variasi $1 / 2 \lambda, 1 \lambda, 11 / 4 \lambda, 11 / 2 \lambda$, dan $2 \lambda$

Dengan variasi $1 / 2 \lambda, 1 \lambda, 11 / 4 \lambda, 1$ $1 / 2 \lambda$, dan $2 \lambda$ pada antena array vertikal arah polaradiasi maksimum dari antena mengarah pada sudut $160^{\circ}$ dengan daya pancar $-57,34 \mathrm{db}$ dan daya pancar 
minimum mengarah pada sudut $240^{\circ}$ dengan daya pancar $-70,67 \mathrm{db}$

Hasil pengukuran antena arrray vertikal diatas dengan fariasi $1 / 2 \lambda, 1 \lambda, 2$ $\lambda, 1 \lambda, 1 / 2 \lambda$ dapat digambarkan dalam bentuk polar berikut:

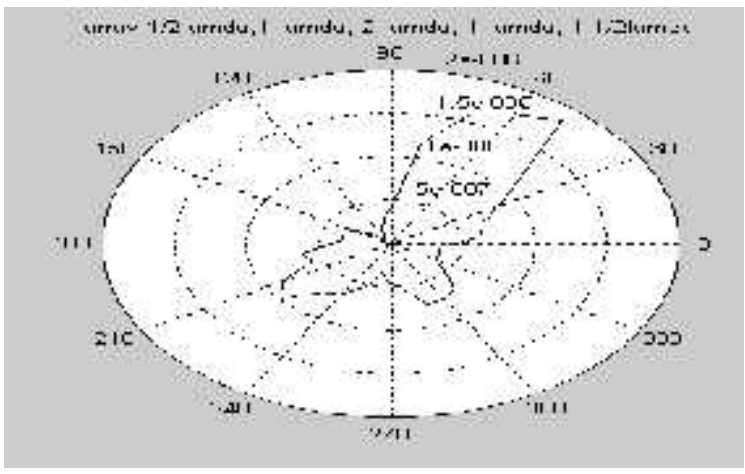

Gambar 23 Hasil polaradiasi antena arrray vertikal

dengan variasi $1 / 2 \lambda, 1 \lambda, 2 \lambda, 1 \lambda, 1 / 2 \lambda$

Pada gambar diatas dapat di ketahui bahwa polaradiasi antena array vertikal dengan variasi $1 / 2 \lambda, 1 \lambda, 2 \lambda, 1 \lambda, 1 / 2 \lambda$ arah pancaran maksimum mengarah pada sudut $50^{\circ}$ dengan daya pancar $57,34 \mathrm{db}$ dan arah pancaran minimum mengarah pada sudut $120^{\circ}$ dengan daya pancar $-71,34 \mathrm{db}$

Berdasarkan data-data diatas dapat dianalisa bahwa antena array memiliki polaradiasi yang berbeda-beda. Pada antena array 5 element horizontal dengan kombinasi panjang kabel catu $\lambda, \lambda, \lambda, \lambda$, $\lambda$ polaradiasinya maksimum mengarah pada sudut $90^{\circ}$ dan $100^{\circ}$ dengan daya $58,67 \mathrm{dBm}$, dan daya terima minimum pada sudut $220^{\circ}$ yaitu $-68,67 \mathrm{dBm}$. Pada kombinasi panjang kabel fasa $1 / 2 \lambda, 1 \lambda$, $11 / 4 \lambda, 11 / 2 \lambda$, dan $2 \lambda$ polaradiasi yang dihasilkan adalah maksimum pada sudut $310^{\circ}$ daya terima $-57,67 \mathrm{dBm}$, dan daya terima minimum pada sudut $210^{\circ}$ dengan daya $-72,34 \mathrm{dBm}$. Pada kombinasi panjang kabel fasa $1 / 2 \lambda, 1 \lambda, 2 \lambda, 1 \lambda$, $1 / 2 \lambda$ polaradiasi yang dihasilkan adalah pada sudut $40^{\circ}$ daya terima $-56,67 \mathrm{dBm}$, dan daya terima minimum pada sudut $230^{\circ}$ dengan daya $-71 \mathrm{dBm}$. Pada kombinasi antena array 5 element vertikal dengan panjang kabel fasa $\lambda, \lambda$, $\lambda, \lambda, \lambda$, daya terima maksimum pada sudut $30^{\circ}$ dengan daya $-53 \mathrm{dBm}$, dan daya minimum pada sudut $180^{\circ}$ dengan daya $-66 \mathrm{dBm}$. Pada kombinasi panjang kabel fasa $1 / 2 \lambda, 1 \lambda, 11 / 4 \lambda, 11 / 2 \lambda$, dan $2 \lambda$, daya terima maksimum pada sudut $160^{\circ}$ dengan daya $-57,34 \mathrm{dBm}$, dan daya minimum pada sudut $240^{\circ}$ dengan daya $70,67 \mathrm{dBm}$. Pengarahan pola radiasi dari antena array ini kurang efektif seharusnya pada keadaan panjang kabel catu $\lambda, \lambda, \lambda, \lambda, \lambda$ dengan polarisasi antena vertikal polaradiasi dari antena mengarah pada sudut $0^{\circ}$ sedangkan setelah dilakukan pengukuran polaradiasi dari array mengarah pada sudut $30^{\circ}$. Ini bisa di sebabkan karena sinyal pantul pada saat pengujian antena, dan penggunaan komponen dalam rangkaian penggeser phasa. kemudian dari hasil ini dapat dihitung pergeseran $(\alpha)$ dari arah polaradiasi yang dihasilkan kombinasi panjang kabel.

\section{Pengukuran Gain Antena}

Pengukuran gain antena dilakukan dengan cara membandingkan sebuah antena standar dengan antena yang akan diukur. Antena standar biasa digunakan sebagai antena referensi. Dalam prakteknya antena standar yang digunakan bisa berupa antena dipole $1 / 2$ $\lambda$. Hasil Pengukuran yang didapatkan terlihat pada tabel 4 dibawah ini:

Tabel 4 Hasil pengukuran daya pancar dan daya penerima antena

\begin{tabular}{l|c|c|c}
\hline \multicolumn{1}{c|}{ Antena } & $\begin{array}{c}\text { Frekue } \\
\mathrm{nsi} \\
(\mathrm{MHz})\end{array}$ & $\begin{array}{c}\text { Daya } \\
\text { Pancar } \\
(\mathrm{dBm})\end{array}$ & $\begin{array}{c}\text { Daya } \\
\text { Terima } \\
(\mathrm{dBm})\end{array}$ \\
\hline Dipole $1 / 2 \lambda$ horizontal & 850 & +16 & -59 \\
Dipole $1 / 2 \lambda$ vertikal & 850 & +16 & -57 \\
Array $\lambda$ sama horizontal & 850 & +16 & -66 \\
Array $1 / 2 \lambda, 1 \lambda, 11 / 4 \lambda, 11 / 2 \lambda, 2 \lambda$ & 850 & +16 & $-66,34$ \\
Array1/2 $\lambda, 1 \lambda, 2 \lambda, 1 \lambda, 1 / 2 \lambda$ & 850 & +16 & $-60,34$ \\
Array $\lambda$ sama vertikal & 850 & +16 & $-55,34$ \\
Array $1 / 2 \lambda, 1 \lambda, 11 / 4 \lambda, 11 / 2 \lambda, 2 \lambda$ & 850 & +16 & -62 \\
Array $1 / 2 \lambda, 1 \lambda, 2 \lambda, 1 \lambda, 1 / 2 \lambda$ & 850 & +16 & -63 \\
\hline \multicolumn{2}{|c|}{}
\end{tabular}

Berdasarkan hasil pengukuran dapat disimpulkan bahwa antena array memiliki gain yang tinggi di bandingkan antena referensi dipole $1 / 2 \lambda$. Secara 
teori tentang antena array gain antena array lebih besar dari antena individunya. Ini berarti bahwa antara alat yang dibuat telah mempunyai hasil yang sama secara teorinya.

\section{KESIMPULAN}

Berdasarkan proses pengerjaan alat, hasil pengukuran dan pengujian serta analisa yang telah dilakukan, maka dapat diambil kesimpulan sebagai berikut :

1. Bentuk polaradiasi yang dihasilkan antena array berbedabeda sesuai dengan bergesernya fasa (phase shifter) antar elemen antena array.

2. Dengan penggunaan mikroprosesor, pengalihan panjang kabel transmisinya dapat dilakukan dengan cepat dan mudah serta arah polaradiasi dari antena array dapat di atur secara elektronik tanpa merubah posisi antena.

3. Gain antena array lebih besar dari antena dipole sebagai antena referensinya yaitu $7 \mathrm{dBm}$ dengan kondisi phasa dari antena array sama.

4. Bandwith dari antena array yang dibuat sebesar $9 \mathrm{MHz}$ yaitu dari frekuensi $832 \mathrm{MHz}$ sampai 841 $\mathrm{MHz}$. Bandwith ini merupakan frekuensi kerja antena.

\section{DAFTAR PUSTAKA}

Andi Nalwan Paulus, Panduan Praktis Teknik Antarmuka Dan Pemograman Mikrokontroler AT89C51, PT Elex Media Komputindo, Jakarta, 2003

Firdaus, Ramiati, Ratna Dewi, Ahmad Dahlan, Pembuatan Penggeser Fasa (Phase Shifter) Gelombang Frekuensi Radio $700 \mathrm{MHz}$ untuk Aplikasi Praktikum antena Arrray dan Radar, Jurnal Ilmiah Elektron, Vol.3 No. 1 Edisi Juni 2011.
Mackenzie Scott, The Microcontroller 8051, Prentice Hall, Englewood Cliffs, New Jersey, Columbus, Ohio, 1992

Firdaus dan Yulindon, Modul Ajar Teori dan Perencanaan Antena. Politeknik Negeri Padang.

Liang Chi Shen dan Jin Au Kong. Aplikasi Elektromagnetik, 2001.

Robert R. Romanofsky, Array Phase Shifters: Theory and Technology, NASA, 2007. 
ISSN :2085-6989 